$\begin{gathered}\text { Dicle Üniversitesi Veteriner Fakültesi Dergisi } \\ \text { https://dergipark.org.tr/tr/pub/duvetfd } \\ \text { Araştırma Makalesi/Research Article } \\ \text { Dicle Üniv Vet Fak Derg 2021;14(2):131-135 } \\ \text { DOl: 10.47027/duvetfd.991646 }\end{gathered} \quad$ e-ISSN:1308-0679
ISSN:1307-9972

\title{
İneklerde Subklinik Mastitis Tanısında Amiloid A ve C-Reaktif Protein Düzeylerinin Değerlendirilmesi
}

\author{
Tuğba ARMAĞAN AYDiN ${ }^{1, \bowtie, a}$, Birten EMRE ${ }^{1, b}$
}

${ }^{1}$ Harran Üniversitesi, Veteriner Fakültesi Doğum ve Jinekoloji Anabilim Dalı, Şanlıurfa, TÜRKiYE

aORCID: 0000-0002-7453-3745; bORCID: 0000-0001-8785-417X

\begin{tabular}{ccc}
\hline Geliş Tarihi/Received & Kabul Tarihi/Accepted & Yayın Tarihi/Published \\
06.09 .2021 & 07.11 .2021 & 31.12 .2021 \\
\hline
\end{tabular}

Öz

Subklinik mastitis, ineklerde en yaygın gözlenen önemli yangısal sürü hastalıklarından birisidir. Bu çalışmada hastalığın tanısında süt ve kanda amiloid A (AA) ve C-reaktif protein (CRP) parametrelerinin yeni bir tanı seçeneği olarak ortaya konulması amaçlanmıştır. Çalışma laktasyonun farklı dönemlerinde bulunan toplam 40 adet Holstein ırkı sağmal inek üzerinde yürütüldü. Strip cup muayenesinin a rdından süt ve meme muayenesinde herhangi bir fiziksel bozukluk gözlenmeyen meme loblarına subklinik mastitis (SCM) tanısı amacıyla Kaliforniya Mastitis Testi (CMT) uygulandı. CMT'de sadece Ş ve +1 skorlar SCM pozitif olarak çalışmaya dahil edildi. Bu sonuçlar doğrultu sunda 2 grup oluşturuldu; Grup I ( $n=40)$, CMT yönünden her 4 meme lobu da negatif olan ineklere ait serum ve süt örnekleri, Grup II ( $n=40)^{\prime} y e$ ise CMT'ye göre pozitif olan serum ve süt örnekleri dahil edildi. Süt ve kan serumunda amiloid A ve CRP düzeyinin belirlenmesinde ticari ELISA kitleri kullanıldı. Çalışmada, ortalama AA düzeyleri sağlıklı olan serum ve süt örneklerinde sırasıyla $0.68 \pm 0.00 \mathrm{ng} / \mathrm{ml} ; 0.66 \pm 0.00 \mathrm{ng} / \mathrm{ml} ; \mathrm{SCM}$ olanlarda ise sırasıyla $2.04 \pm 0.06 \mathrm{ng} / \mathrm{ml}$ ve $1.84 \pm 0.06 \mathrm{ng} / \mathrm{ml}$ belirlendi $(p<0.001)$. CRP düzeyleri ise, sağlıklı olanlarda serum ve sütte sırasıyla $0.17 \pm 0.00 \mathrm{mg} / \mathrm{ml} ; 0.15 \pm 0.00 \mathrm{mg} / \mathrm{ml}, \mathrm{SCM}$ olanlarda ise sırasıyla $0.55 \pm 0.01 \mathrm{mg} / \mathrm{ml}$ ve $0.53 \pm 0.01 \mathrm{mg} / \mathrm{ml}$ olarak hesaplandı (p<0.001). Gruplar arası akut faz protein parametreleri değerlendirmesinde; serum ve süt AA ve CRP değerlerinin istatiksel olarak gruplar arasında önemli derecede farklı olduğu tespit edildi. Sonuç olarak AA ve CRP'nin subklinik masititisi belirlemede öne çıkabileceği düşünülmektedir.

Anahtar Kelimeler: Amiloid A, akut faz proteini, c- reaktif protein, inek, subklinik mastitis

Evaluation of Amyloid A and C-Reactive Protein Levels in The Diagnosis of Subclinic Mastitis in Cows

Abstract

Subclinical mastitis is one of the most common inflammatory dairy herd diseases in cows. In this study, we aimed to present amyloid A (AA) and C-reactive protein (CRP) parameters in milk and blood as a new diagnostic option in the diagnosis of subclinical mastitis. The study was carried out on a total of 40 Holstein cows in different stages of lactation. After the strip cup examination, the California Mastitis Test (CMT) was applied for the diagnosis of subclinical mastitis (SCM).to the mammary lobes in which no physical symptom was observed in the milk and udder examination. Only $S$ and +1 scores in CMT were included in the study as SCM positive. In line with these results, 2 groups were formed; serum and milk samples from cows with negative CMT in all 4 mammary lobes were included in Group I ( $n=40$ ), and serum and milk samples positive for CMT in Group II $(n=40)$ were included. In the study, mean AA levels were $0.68 \pm 0.00 \mathrm{ng} / \mathrm{ml} ; 0.66 \pm$ $0.00 \mathrm{ng} / \mathrm{ml}$ in healthy serum and milk samples, respectively. In those with SCM, $2.04 \pm 0.06 \mathrm{ng} / \mathrm{ml}$ and $1.84 \pm 0.06 \mathrm{ng} / \mathrm{ml}$ were determined, respectively $(p<0.001$ ). CRP levels were $0.17 \pm 0.00 \mathrm{mg} / \mathrm{ml} ; 0.15 \pm 0.00 \mathrm{mg} / \mathrm{ml}$ in serum and milk in healthy group, respectively. It was calculated as $0.55 \pm 0.01 \mathrm{mg} / \mathrm{ml}$ and $0.53 \pm 0.01 \mathrm{mg} / \mathrm{ml}$ in SCM, respectively $(p<0.001)$. In the evaluation of acute phase protein parameters between groups; It was determined that AA and CRP milk and blood serum values were statistically significantly different between the groups. As a result, it is thought that AA and CRP may be prominent in determining subclinical mastitis.

Key Words: Amyloid A, acute phase protein, c-reactive protein, cows, subclinical mastitis

\section{GíRiş}

Subklinik mastitis (SCM) süt veriminde ve kalitesinde değişime neden olurken hayvan refahını olumsuz etkilemekte ve önemli ekonomik kayıplara neden olmaktadır. Mastitisin reprodüktif sisteme, ineğe, buzağıya ve halk sağlığına olan etkileri de göz önünde bulundurulduğunda ekonomik kayıp daha da artmaktadır. Bu kayıpların en aza indirilmesi için erken tanı ve doğru tedavi oldukça önemli hale gelmektedir $(1,2)$.

Sistemik veya lokal bir belirtinin gözlenmediği SCM olgularının tanısı için yaygın olarak somatik hücre sayımı (SHS), sütte patojen etkenlerin izolasyonu ve kanda biyokimyasal değerlerde meydana gelen değişimler değerlendirilmektedir $(3,4)$. Son zamanlarda bu yöntemlere ek olarak memede oluşan yangıya bağlı olarak artış gösteren akut faz proteinleri (AFP), yangı mediatörleri ve oksidatif stres parametreleri de araştırılmaktadır (4,5). Günümüzde özellikle AFP'leri hem insan hem de hayvan sağ Iığında önemli tanı biyobelirteçleri haline gelmiştir (6). Akut faz proteinler akut faz yanıta cevap olarak karaciğer tarafından sentezlenen proteinler olup günümüzde bilinen çok sayıda farklı özelliğe sahiptirler. Bu 
proteinler sağlıklı hayvanlarda önemsiz düzeyde bulunurken yangı sırasında hızla artmakta ve bir yangı indikatörü olarak rol oynamaktadırlar (4). Bunlardan Serum amiloid A'nın (SAA) doku hasarından kısa bir süre sonra (24 saat) plazma ve/veya diğer vücut sıvılarında (100 kez) hızlı ve yoğun artışı (18-20) bu proteini, bir yangı belirteci olarak sağlık durumunun izlenmesi, tedaviye verilen yanıtların değerlendirilmesinde ve AFP'nin oluşmasında önemli kılmaktadır (7-9). Serum amiloid $A^{\prime}$ nın atlarda ve sığırlarda karaciğer dışında süt amiloid A (MAA) gibi farklı izoformlarının da olduğu rapor edilmiştir $(4,10)$ Sığırlarda süte spesifik form olan MAA'nın diğer SCM tanısal belirteçlerine göre avantajı, meme epitel hücreleri tarafından lokal olarak sentezlendiğinden dolayı süte spesifik olması ve bu nedenle de mastitis tanısında hassas ve güvenilir bir biyobelirteç olduğu belirtilmektedir. MAA düzeyinin SCM'deki diğer bir avantajı da sağlıklı hayvanlarda tespit edilemeyecek düzeylerde bulunmasıdır. Akut faz proteinlerinden $\mathrm{C}$ reaktif protein ise (CRP) bakteriyel-viral ya da akut-kronik hastalıkları ayırt etmekte kullanılabileceği ve enfeksiyon durumlarında hızlıca arttığı belirlenmiştir (11-13). Bu protein oksitlenmiş düşük yoğunluklu lipoproteinleri ve inflamasyona neden olan kompleman sistemini aktive edebileceği tespit edilmiştir Ayrıca CRP'nin sürü sağlığını değerlendirmesi açısından da önemli olduğu bildirilmiştir $(4,14)$.

Çalışmada subklinik mastitisli ineklerde akut faz proteinlerinden amiloid $A$ (SAA/MAA) ve $C$ reaktif protein (CRP) biyobelirteçlerinin hem serum hem de süt örneklerinde değerlendirilmesi amaçlanmıştır.

\section{MATERYAL VE METOT}

\section{Hayvan Materyali}

Bu çalışma, HRÜ-HADYEK' in 19/09/2019 tarih ve 21862 sayılı etik kurul izni ile gerçekleştirildi. Çalışmada, yaşları 3-5 arasında değişen, daha önce en az bir doğum yapmış, laktasyon döneminde olan, bir örnek beslenen ve herhangi bir sağlık problemi bulunmayan toplam 40 adet Holstein ırkı süt ineği çalışmaya dahil edildi. Günde iki kez makinalı sağım uygulanan işletmede, inekler kış aylarında kapalı, bahar ve yaz aylarında ise açık padoklarda serbest halde barındırılmaktaydılar.

\section{Çalışma Düzeni ve Gruplandırma}

İneklerin mastitis yönünden incelenmesi Kasım-Nisan ayları arasında gerçekleştirildi. Çalışma, laktasyonun 1-7. ayları arasında bulunan inekler üzerinde yürütüldü. Çalışmaya dahil edilen ineklerde genel sağlık kontrolü ve meme muayenesini takiben yapılan strip cup ile ön süt muayenesinde sütte herhangi bir fiziksel bozukluk gözlenmeyen (klinik mastitis belirtisi) meme loblarına subklinik mastitis tanısı amacıyla Kaliforniya Mastitis Testi (CMT) testi uygulandı. Klinik mastitis belirtisi göstermeyen ineklerde nitel somatik hücre sayıları, CMT testi kullanılarak değerlendirildi. Sonuçlar Schalm ve ark. (1971)'nın kriterleri göz önünde bulundurularak test küreğinde oluşan jelin kıvamına göre yorumlandı.

Kaliforniya Mastitis Test sonuçlarına göre 2 grup oluşturuldu; Grup I ( $n=40)$, CMT yönünden her 4 meme lobu da negatif olan 20 ineğe ait süt ve kan serum örnekleri kontrol grubuna (Grup I), CMT'ye göre \$̧ ve +1 sonuç veren 20 ineğe ait süt ve kan serum örnekleri ise Grup II ( $n=40)^{\prime}$ ye dahil edildi. Çalışmada daha spesifik sonuçlara ulaşmak amacıyla $\mathrm{CMT}^{\prime}$ de sadece Ş ve +1 skorlar SCM pozitif olarak çalışmaya dahil edildi. Meme loblarında +2 ve +3 CMT skorlarına sahip meme lobları ise ciddi/ileri SCM olduğu ve bu CMT skorlarının biyokimyasal parametrelerin değerlerini belirgin bir şekilde değiştireceği göz önünde bulundurulduğundan dolayı çalışmaya dahil edilmedi.

\section{Kan ve Süt Örneklerinin Alınması}

Süt ve kan örnekleri sabah sağımından hemen önce alındı. Bu amaçla, çalışma materyalini oluşturan süt örnekleri National Mastitis Council (NMC) tarafından bildirilen şartlarda aseptik şekilde toplandı (16). Kan örnekleri ise 10 ml'lik vakumlu, antikoagulan içermeyen cam tüplere alındı. Alınan örnekler 3000 devir/dk'da 15 dakika santrifüj edildi. Elde edilen kan serum ve süt örnekleri eppendorf tüplere aktarılarak analizleri yapılıncaya kadar derin dondurucuda $-20^{\circ} \mathrm{C}^{\prime}$ de saklandı.

\section{Amiloid A ve C Reaktif Proteinin Ölçülmesi}

Süt ve kan serum örnekleri analizden hemen önce $+4^{\circ} \mathrm{C}^{\prime} \mathrm{de}$ çözdürülerek oda ısısında bekletildi. Süt ve kan serumunda amiloid A düzeyinin belirlenmesinde ticari ELISA kiti (CloudClone SEA885Bo-96) kullanıldı. CRP düzeyinin belirlenmesinde ticari ELISA kiti (Rel Assay, E023Bo-96) kullanıldı. Bütün örnekler test prensibine göre çalışıldı. Enzim-substrat reaksiyonu, spektrofotometrik olarak $450 \mathrm{~nm} \pm 10 \mathrm{~nm}$ (Amiloid A) ve $450 \mathrm{~nm} \pm 2 \mathrm{~nm}$ (CRP) dalga boylarında optik dansiteleri belirlendi.

\section{İstatiksel Analiz}

Verilerin istatistiki analizi Statistical Package for the Social Sciences (SPSS for Windows; version 22.0) paket programı ile gerçekleştirildi. Değişkenlerin normal dağılıma uygunluğu görsel (histogram ve olasılık grafikleri) ve analitik yöntemlerle (Kolmogorov-Smirnov/Shapiro-Wilk testleri) incelendi. Tanımlayıcı analizler normal dağılan değişkenler için ortalama \pm standart hata şeklinde verildi. illgili verilerin normal dağılım gösterdiği belirlendiğinden bu parametreler sağlıklı ve subklinik mastitisli gruplar arasında Independent samples t-test kullanılarak karşılaştırıldı. P-değerinin 0.05'in altında olduğu durumlar istatistiksel olarak anlamlı sonuçlar şeklinde değerlendirildi.

\section{BULGULAR}

Gruplar arası akut faz protein parametreleri değerlendirmesinde; amiloid A ve C reaktif protein süt ve kan serum değerlerinin istatiksel olarak gruplar arasında önemli derecede farklı olduğu tespit edildi ( $p<0.001$ ) (Grafik 1, Grafik 2).

Ortalama AA düzeyleri sağlıklı süt ve kan serumunda sırasıyla $0.66 \pm 0.00 \mathrm{ng} / \mathrm{ml} ; 0.68 \pm 0.00 \mathrm{ng} / \mathrm{ml}$, subklinik mastitisli olanlarda ise sırasıyla $1.84 \pm 0.06 \mathrm{ng} / \mathrm{ml} ; 2.04 \pm 0.06 \mathrm{ng} / \mathrm{ml}$ olarak hesaplanmıştır. CRP düzeyleri ise, sağlıklı süt ve kan serumunda sırasıyla $0.15 \pm 0.00 \mathrm{mg} / \mathrm{ml} ; 0.17 \pm 0.00 \mathrm{mg} / \mathrm{ml}$, subklinik mastitis grubunda ise sırasıyla $0.53 \pm 0.01 \mathrm{mg} / \mathrm{ml}$ ve $0.55 \pm 0.01 \mathrm{mg} / \mathrm{ml}$ olarak hesaplanmıştır (Tablo 1 ). 
Grafik 1. Gruplar arası ortalama serum amiloid $A(S A A)$ ve süt amiloid A(MAA) değerleri

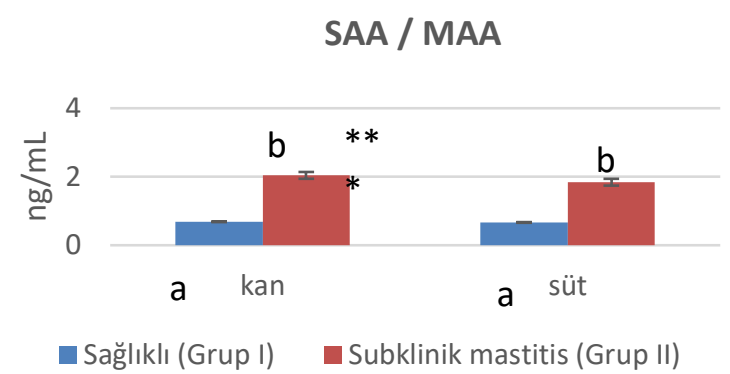

$* * *: p<0.001$. Sütun grafikteki değerler ortalama $\pm S^{\prime}{ }^{\prime}{ }^{\prime} i$ ifade etmektedir. Grup I ( $n=40)$, Grup II $(n=40)$
Grafik 2. Gruplar arası ortalama süt ve serum C-Reaktif protein (CRP) değerleri

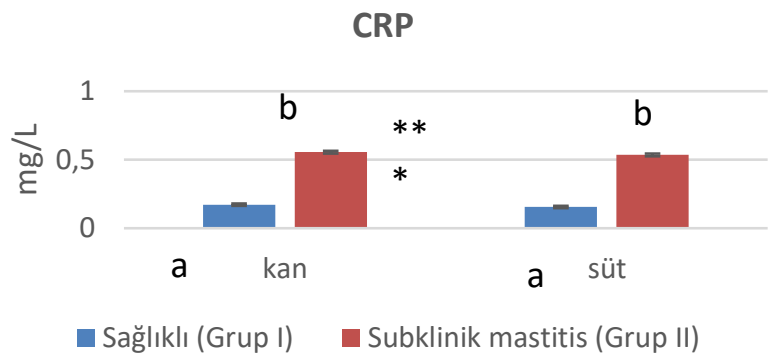

$* * *: p<0.001$. Sütun grafikteki değerler ortalama \pm SEM'i ifade etmektedir. Grup I $(n=40)$, Grup II $(n=40)$

Tablo 1. Süt ve kan serumunda AA ve CRP düzeyleri

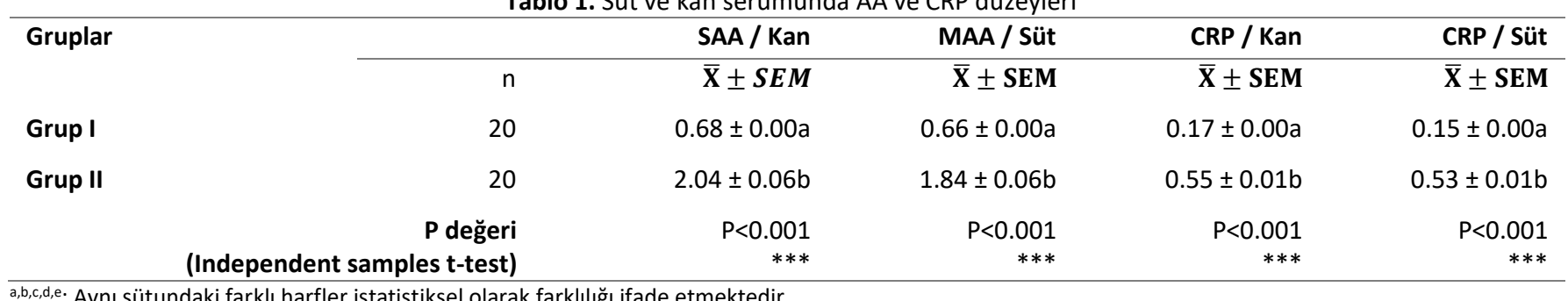

$\mathrm{a}, \mathrm{b}, \mathrm{c}, \mathrm{d}, \mathrm{e}:$ Aynı sütundaki farklı harfler istatistiksel olarak farklılığı ifade etmektedir.

***: $\mathrm{p}<0.001, \overline{\mathrm{X}} \pm$ SEM: Ortalama \pm Standart Error of Means, SAA: Serum Amiloid A, MAA: Milk Amiloid A, CRP: C-Reaktif Protein

\section{TARTIŞMA VE SONUÇ}

Subklinik mastitis, işletmelerde en yaygın gözlenen hastalıklardan birisidir. Sürüde hızlı ve gizli bir şekilde yayılabilmesi nedeniyle büyük risk oluşturmakta ve bu sorun hastalığın tamamen eradike edilmesini zorlaştırmaktadır. Mastitiste, korunma en etkili yol olup uygulanacak akılcı tanı ve tedavi yöntemleri ise bu hastalığın ilerleyişinin durdurulmasında oldukça önemlidir (17). Sunulan çalışmada bu hastalığın tanısında süt ve kanda amiloid $A(A A)$ ve C-reaktif protein (CRP) düzeylerinin ortaya konulması amaçlanmıştır.

Mastitis tanısında yaygın olarak somatik hücre sayımı, mikrobiyolojik muayene, enzim testleri ve AFP gibi birçok yöntem kullanılmaktadır $(18,19)$. Jadhav ve ark. (2018)'nın SCM tanısında meme bezindeki yangının başlangıcının en iyi göstergesinin sütte somatik hücre sayısında artışın görülmesi olduğunu ifade etmişlerdir. Sargeant ve ark. (21) ise CMT'nin, SCM'lerin \%84'ünde, enfeksiyonun belirlenmesi ve sürü sağ Iığının izlenmesinde güvenilir olduğunu bildirmiştir. Çalışmamızda CMT sonuçlarına göre alınan örneklerin tamamında azami düzeyde de olsa SAA, MAA ve CRP düzeyleri ölçülebilmiştir. Dolasıyla CMT'nin subklinik mastitis tanısında sahada basit ve kolay bir yöntem olarak kullanılabilirliğinin gözlendiği bununla birlikte özellikle CMT negatif olan örneklerde SHS ve bakteriyolojik incelemenin gerekliliği gözlendi.

Wollowski ve ark. (2021) sütte katelisidin, MAA ve Haptoglobulin (Hp) ölçümünün, subklinik veya klinik mastitisli meme loblarını tespit etmek için güvenilir bir yöntem olduğunu, MAA düzeyinin sadece şiddetli klinik mastitis vakalarında $(1.81 \mu \mathrm{g} / \mathrm{mL})$ hafif olanlara $(1.28 \mu \mathrm{g} / \mathrm{mL})$ göre daha yüksek değerde olduğunu tespit etmişlerdir. Staphylococcus aureus pozitif subklinik mastitisli ineklerde kontrol sütüne göre, Hp ve SAA düzeylerindeki artışlar istatistiksel olarak anlamlı olarak belirlenmiştir (23). Akerstedt ve ark. (2011) çaIışmalarında mastitisli hayvanlarda ortalama SAA düzeyini
$336.4 \pm 459.4 \mathrm{mg} / \mathrm{l}$ olarak belirlemişlerdir. Otsuka ve ark. (2021) çalışmalarında mastitisi belirlemede SAA'nın diğer AFP'lere göre daha etkin olduğunu ve SAA konsantrasyonunu klinik mastitiste $(44.90 \mathrm{mg} / \mathrm{l})$ subklinik mastitise (10.70 $\mathrm{mg} / \mathrm{l})$ göre önemli derecede yüksek olarak belirlemişlerdir. Bununla birlikte Gerardi ve ark. (2009) çalışmalarında MAA'nın mastitis durumlarında ciddi düzeyde arttığı ancak subklinik ve klinik mastitis arasında ise fark gözlenmediğini belirlemişlerdir. SHS ve bakteriyolojik incelemeler doğrultusunda grupların oluşturulduğu bir çalışmada MAA konsantrasyonu ve SHS arasında güçlü bir pozitif korelasyon ve doğru orantı oluştuğu gözlenmiştir (12). Sağlıklı, subklinik ve klinik mastitisli gruplarda yapılan diğer bir çalışmada ise SHS ile MAA arasında önemli bir korelasyon tespit edilirken, SAA ve MAA arasında hiçbir korelasyon kaydedilmiş olup MAA'nın subklinik mastitin potansiyel bir fizyolojik belirteci olduğunu göstermiştir (26). Subklinik mastitisli ineklerde Amiloid A'nın sütteki değeri sağlıklı olanlara göre (sırasıyla 3600.5 ve 790.2 $\mathrm{ng} / \mathrm{mL}$ ) anlamlı olarak daha yüksek, bununla birlikte her iki grubun SAA seviyelerinde ise ( 2.72 ve $2.68 \mathrm{ng} / \mathrm{mL}$ ) anlamlı bir farklılık şekillendiği rapor edilmiştir (27). Thomas ve ark. (2015) mastitis tespiti için yaptıkları çalışmada ortalama bazal konsantrasyonun MAA'da $0.96 \mu \mathrm{g} / \mathrm{ml}$ ve CRP'de ise 22.4 $\mathrm{ng} / \mathrm{ml}$ olarak belirlenmiştir. Mastitisli ineklerde serum CRP konsantrasyonunun (1083 $\pm 93 \mathrm{ng} / \mathrm{mL}$ ), sağlıklı olanlara göre 10 kat daha fazla olduğu ( $82 \pm 66 \mathrm{ng} / \mathrm{mg}$ ) tespit edilmiştir (28). Insanlarda mastitis olgularında lokal ve sistemik belirtilerin şiddetine benzer şekilde hem süt hem de serumda CRP düzeyinin arttığı kaydedilmiştir (29). Hamann ve ark. (1997) ise CRP kapasitesinin enfekte ve sağlıklı meme loblarını ayırt etmede zayıf olduğunu vurgulamıştır. Benzer şekilde ineklerdeki inflamasyona bağlı olarak pratikte CRP'nin değişmediği için ineklerde akut faz proteini olmadığı, yangı ve enfeksiyon durumlarına bağlı olarak da arttığı ifade edilmektedir 
$(31,32)$. Bu çalışmalar ışığında, CRP, SAA ve özellikle MAA konsantrasyonunun mastitisin şiddetinin artışı ile paralel bir seyir izlediği, bununla birlikte CMT veya SHS'nın derecesine, bakteri türüne ve yoğunluğuna bağlı olarak değiştiği görülmüştür. Sunulan çalışmada kan serum ve süt örneklerinde ortalama amiloid A düzeyleri sağlıklı olanlarda sırasıyla 0.68 $\mathrm{ng} / \mathrm{ml} ; 0.66 \mathrm{ng} / \mathrm{ml}$, SCM olanlarda ise sırasıyla $2.04 \mathrm{ng} / \mathrm{ml}$ ve $1.84 \mathrm{ng} / \mathrm{ml}$ olarak hesaplanmıştır $(\mathrm{p}<0.001)$. CRP düzeyleri ise, serum ve sütte sırasıyla $0.17 \mathrm{mg} / \mathrm{ml} ; 0.15 \mathrm{mg} / \mathrm{ml}, \mathrm{SCM}$ olanlarda ise sırasıyla $0.55 \mathrm{mg} / \mathrm{ml}$ ve $0.53 \mathrm{mg} / \mathrm{ml}$ olarak hesaplanmıştır $(p<0.001)$. Bu AFP düzeylerinin yaptığımız çalışmaya paralel diğer çalışmalarla $(22,23)$ benzer sınırlarda olduğu ve çoğu araştırmaya benzer şekilde mastitis olgularında belirgin olarak artış (en az 3 kat) gösterdiği tespit edilmiştir $(22,23,25)$. Bununla birlikte Lehtolainen ve ark. (2004)'nın çalışmasından farklı olarak bazı araştırmacıların $(11,26)$ sonuçlarına benzer şekilde sunulan çalışmada da SAA ve MAA değerleri arasında anlamlı bir farklılık belirlenmemiştir. Çalışmada MAA düzeyinin sütte artma nedeninin yangıya bağıı lokal sentezinin olduğu, CRP düzeyindeki artışın ise yangıya bağlı kan damarlarından sızıntı yaparak sütün içine geçmesinden kaynaklanabileceği düşünülmektedir. MAA süte spesifik olması nedeniyle tanıda yüksek doğruluk oranına sahip olduğu düşünülmektedir. Çalışmamızda CRP düzeyinin SAA'ya benzer şekilde sağlıklı örneklerde düşük, SCM'li örneklerde yüksek olduğu görülmüştür. CRP'nin subklinik masititisi belirlemede öne çıkabileceği düşünülmektedir.

Sonuç olarak; bu çalışmanın yapıldığı işletmede subklinik vakaların varlığı SCM tanısının önemini yeniden hatırlatmıştır. SCM'nin meme sağlığı açısından bu parametreler ile birlikte değerlendirilmesi tanı da önemli düzeyde fayda sağlayacaktır. Ayrıca SCM tanısında SAA/MAA ve CRP ile ilgili yeni çalışmaların yapılması gerektiği ve ileride yapılacak çaIışmalarda hayvan ve örneklem sayısının arttırılmasının yanında çalışmalara tanıda SHS, total bakteri sayısı ve bakteriyolojik incelemelerin de eklenmesinin daha fazla fayda sağlayacağı kanısına varılmıştır.

\section{TEŞEKKÜR}

Bu çalışma, Harran Üniversitesi Bilimsel Araştırma Projeleri Koordinatörlüğü tarafından 19252 proje numarası ile desteklenmiştir. Birinci isim yazarın aynı isimli yüksek lisans tezinden özetlenmiştir. Çalışma 17-19 Mayıs 2021'de 6. Ulusal - 2. Uluslararası sürü sağlığı ve yönetimi e-kongresinde sözlü olarak sunulmuştur.

Çalışma sürecindeki destek ve katkılarından dolayı Harran Üniversitesi Veteriner Fakültesi Doğum ve Jinekoloji $A D$, Mikrobiyoloji AD Öğretim Üyeleri ve lisansüstü öğrencilerine, aynı zamanda istatiksel değerlendirme sürecindeki katkılarından dolayı Dr. Öğr. Üyesi Tuğra AKKUŞ’a en içten dileklerimizle teşekkür ederiz.

\section{ÇIKAR ÇATIŞMASI}

Araştırmamızın herhangi bir kurum, kuruluş, kişi ile mali çıkar çatışması yoktur ve yazarlar arasında çıkar çatışması bulunmamaktadır.

\section{KAYNAKLAR}

1. Baştan A. (2010). İneklerde Mastitis, Mastitis Çeşitleri (iç̧inde): Ineklerde Meme Sağlığı ve Sorunları. s. 91-93, 118-122. Kardelen Ofset Matbaacılık, Ankara, Türkiye.

2. Sabuncuoğlu N, Çoban Ö. (2006). Mastitis Ekonomisi. Atatürk Üniversitesi Vet. Bil. Derg. 1 (1-2) 1-5

3. Vural R, Ergün Y, Özenç E. (2016). Büyük Ruminantlarda Mastitis (Içinde): Evcil Hayvanlarda Meme Hastalıkları. Kaymaz M, Fındık M, Rışvanlı A, Köker A, (editörler). Baskı 1. s. 149-159. Medipres Yayıncılık. Malatya, Türkiye.

4. Gökçe I, Bozukluhan K. (2009). Çiftlik Hayvanlarında Önemli Akut Faz Proteinleri ve Bunların Veteriner Hekimlik Alanındaki Kullanımı. Dicle Üniv Vet Fak Derg. 1(1):1- 14.

5. El Nahas SM, El Kasas AH, Mossallem AAA, Abdelhamid MI, Warda M. (2017). A Study on IL8RB Gene Polymorphism as a Potential immuno-compromised Adherent in Exaggeration of Parenteral and Mammo-crine Oxidative Stress During Mastitis in Buffalo. J Adv Res. 8(6): 617-625.

6. Viguier C, Arora S, Gilmartin N, Welbeck K, Kennedy R. (2009). Mastitis detection: current trends and future perspectives. Trend Biotechnol. Aug;27(8):486-93.

7. Tóthová C, Nagy O, Seidel H and Kovác G. (2012). Acute Phase Proteins in Relation to Various Inflammatory Diseases of Calves. Comp. Clin. Pathol.21(5): 1037-1042.

8. Sack GH. (2018). Serum Amyloid A - A review. Mol Med.24:46

9. Jayaraman S, Gantz DL, Haupt and Gursky O. (2017). Serum Amyloid A Forms Stable Oligomers that Disrupt Vesicles at Lysosomal $\mathrm{pH}$ and Contribute to the Pathogenesis of Reactive Amyloidosis. Proc Natl Acad Sci USA. 114(32):E6507-E6515.

10. Baranova IN, Bocharov AV, Vishnyakova TG, et al. (2010). CD36 Is a Novel Serum Amyloid A (SAA) Receptor Mediating SAA Binding and SAA-induced Signaling in Human and Rodent Cells, J.Biol Chem. 285(11):8492-8506.

11. Eckersall PD, Young FJ, McComb C, et al. (2001). Acute Phase Proteins in Serum and Milk From Dairy Cows with Clinical Mastitis. Vet. Rec. 148(2): 35-41.

12. Hussein HA, Razik KH, Gomaa AM, Elbayoumy MK, Abdelrahman KA and Hosein HI. (2018). Milk Amyloid A as a Biomarker for Diagnosis of Subclinical Mastitis in Cattle. Vet World. 11(1):34-41.

13. Sevgisunar N, Şahinduran Ş. (2014). Acute Phase Proteins, Purpose of Uses and Clinical Importance in Animals. MAKÜ Sag. Bil. Enst. Derg. 2(1):50-72

14. Jacob T, Subramani G, Sivaprakasam P, Xavier AP, Mukhopadhyay HK. (2017). Immuno-Detection of C3a, a C3 Complement Activated Product in Mastitis Milk, a Potential Diagnostic Marker. Vet Sci. 23;4(1).

15. Schalm DW, Carroll EJ, Jaın NC. (1971). Bovine Mastitis. Philadelphia: Lea\&Febiger.

16. Harmon RJ, Eberhart RJ, Jasper DE, Langlois BE, Wilson RA. (1990). Microbiological Procedures for Diagnosis of Bovine Udder Infection. National Mastitis Council Inc.

17. Heikkilä AM, Liski E, Pyörälä S, Taponen S. (2018). PathogenSpecific Production Losses in Bovine Mastitis. J Dairy Sci. Oct;101(10):9493-9504

18. Gerardi G, Bernardini D, Azzurra Elia C, Ferrari V lob L, Segato S. (2009). Use of Serum Amyloid A and Milk Amyloid A in the Diagnosis of Subclinical Mastitis in Dairy Cows. J. Dairy Res. J. Dairy Nov;76(4):411-7.

19. Thomas FC, Waterston $M$, Hastie $P$, Parkin $T$, Haining $H$, Eckersall PD. (2015). The major Acute Phase Proteins of Bovine Milk in a Commercial Dairy Herd. BMC Vet Res. Aug 15;11:207 
20. Jadhav PV, Das DN, Suresh KP, and Shome BR. (2018). Threshold Somatic Cell Count for Delineation of Subclinical Mastitis Cases. Vet World. 11(6):789-793.

21. Sargeant JM, Leslıe KE, Shırley JE, Pulkrabek BJ, Lım GH. (2001). Sensitivity and Specificity of Somatic Cell Count and California Mastitis Test for Identifying Intramammary Infection in Early Lactation. J. Dairy Sci. 84: 2018-2024.

22. Wollowski L, Heuwieser W, Kossatz A, et al. (2021). The Value of the Biomarkers Cathelicidin, Milk Amyloid A, and Haptoglobin to Diagnose and Classify Clinical and Subclinical Mastitis. J Dairy Sci. Feb;104(2):2106-2122.

23. Çenesiz S, Gürler H, Fındık A, Çiftci G, Ertekin A, Çenesiz M. (2018). Acute Phase Proteins in Staphylococcus aureus Positive Milks. Etlik Vet Mikrobiyol Derg. 29 (2): 111-115.

24. Akerstedt M, Forsbäck L, Larsen T, Svennersten-Sjaunja K. (2011). Natural Variation in Biomarkers Indicating Mastitis in Healthy Cows. J Dairy Res. Feb;78(1):88-96.

25. Otsuka M, Sugıyama M, Ito T, Tsukano K, Oıkawa S and Suzukı K. (2021). Diagnostic Utility of Measuring Serum Amyloid A with a Latex Agglutination Turbidimetric Immunoassay in Bovine Mastitis: Comparison with Haptoglobin and alpha 1 acid glycoprotein. J. Vet. Med. Sci. 83(2): 329-332.

26. Grönlund U, Sandgren $\mathrm{CH}$, Waller KP. (2005). Haptoglobin and Serum Amyloid A in milk from dairy cows with chronic sub-clinical mastitis Vet. Res. 36:191-198.

27. Bochniarz M, Zdzisińska B, Wawron W, Szczubiał $M$, and Dąbrowski R. (2017). Milk and serum IL-4, IL-6, IL-10, and Amyloid A Concentrations in Cows with Subclinical Mastitis Caused by Coagulase-Negative Staphylococci. J. Dairy Sci. 100:9674-9680.
28. Schrödl W, Krüger M, Hien TT, Füldner M, Kunze R. (1995). Creactive Protein as a new Parameter of Mastitis, Tierärztl. Prax. 23:337-341.

29. Fetherston CM, Wells JI and Hartmann PE. (2006). Severity of Mastitis Symptoms as a Predictor of C-Reactive Protein in Milk and Blood During Lactation. Breastfeedıng Medıcıne. 19:3.

30. Hamann J, Kruger M, Kretschmar M, Nipp B, Gyodi P. (1997). Creactive Protein in Milk of Healthy and Subclinically Diseased Bovineudder Quarters, Milchwissenschaft 52:546-550.

31. Yogeshpriya S and Selvaraj P. (2019). C-Reactive Protein in Veterinary Practice. Dairy and Vet. Sci. J. 13: 555858

32. Eckersall PD, Conner JG. (1988). Bovine and Canine Acute Phase Proteins. Vet. Res. Commun. 169-178.

33. Lehtolaınen T, Røntved C, Pyörälä S. (2004). Serum amyloid A and TNF $\alpha$ in Serum and Milk During Experimental Endotoxin Mastitis. Vet. Res. 35:651-659.

Sorumlu Yazar:

Tuğba ARMAĞAN AYDiN

Harran Üniversitesi Veteriner Fakültesi Doğum

ve Jinekoloji Anabilim Dalı, Şanlıurfa, TÜRKIYE

E-posta: tugba_armagan_@hotmail.com 